\title{
Development of School-based Mental Health Program
}

\author{
Wardiyah Daulay*(D), Sri Eka Wahyuni(D), Mahnum Lailan Nasution(i) \\ Department of Psychiatric Nursing, Faculty of Nursing, Universitas Sumatera Utara, Medan City, North Sumatera Province, Indonesia
}

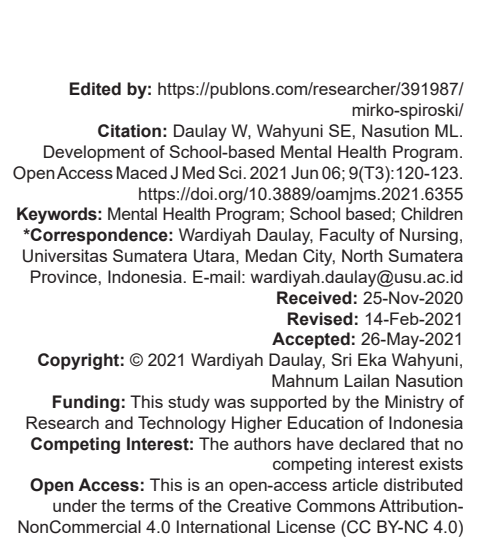

Introduction

Mental health is a crucial thing to consider in all age ranges, including school-aged children. Healthy mental health is characterized by behaviors that correspond to age and developmental tasks. Meanwhile, a child is said to be deviant when the behavior is not appropriate with cultural norms, resulting in lack or disruption of adaptation function [1]

Judging from the population proportion, $40 \%$ consists of children and adolescents aged 0-16 years. It turned out that children and adolescents experienced different mental health disorders, including those with disability, behavioral disorders, learning difficulties, and hyperactivity. Furthermore, a total of $13.5 \%$ under 5 years have a high risk of experiencing developmental disorders, while $11.7 \%$ of pre-school children were at risk of behavioral disorders. Furthermore, the prevalence of mental health issues in children and adolescents tends to increase in line with life and societal problems; therefore, adequate mental health services are required [2].

Despite this large number of students who need treatment, many youths are unable to receive necessary services due to some variables, including stigma, lack of insurance, and transportation [3]. Furthermore, out of the $20 \%$ students with mental health issues, only $16 \%$ received treatment, in which the majority took place in the school setting [4].

Schools have a role and responsibility for school-aged children; therefore, they sought to create a conducive atmosphere. To create this, it is necessary to develop a mental health program in schools to facilitate children to achieve their developmental tasks.

The programs to be developed are based on schools, which have greater management authority (setting goals for quality improvement, planning, implementing improvement plans, and evaluating implementation), having the flexibility of managing resources, and greater participation from groups of interest with schools. Therefore, the expected goal of improving the mental health status could be maximally achieved.

This study aims to create a mental health services program in school-aged children, which will become guidance for teachers, families, and health personnel in optimizing development.

\section{Methods}

This study used action design, and the implementation procedure consists of four stages, 
namely reconnaissance, planning, acting, and reflecting [5]. At the reconnaissance stage (finding the problem), the respondents were 12 teachers in SD Negeri 060891. Meanwhile, at the acting stage, all students in SDN 060891 Medan were the sample. Furthermore, the sampling method was done with total sampling, and all the children in the school were sampled.

Data collected in the reconnaissance stage was recorded and documented in transcript form, which subsequently determined the appropriate theme. At the planning stage, instruments, modules, evaluation sheets, workbooks, and tools were prepared and used to detect mental health status, academic and physical condition of the children. Furthermore, in the acting stage, a school-based mental health program was established. In the program, several stages of identification, assessment, intervention, consultation, facilitation, and training were conducted. After all, actions were completed, it was followed by observation and data comparison of the condition before and after the program was conducted. The final stage was reflecting back by conducting Focus Group Discussion (FGD) about the conducted program.

Data analysis in the reconnaissance and reflecting stage was qualitatively conducted, where data were recorded and documented in transcript form, which determined the appropriate theme. Subsequently, the transcripts were analyzed using content analysis. Quantitative data analysis was conducted based on the collected data of mental health status. Therefore, to determine whether there was any difference in the mental health status of school-aged children before and after the program, data were bivariately analyzed using the dependent t-test.

\section{Results}

\section{Reconnaissance stage}

The themes of FGDs conducted with school teachers were 6: (1) Teachers' knowledge about mental health of school-aged children, (2) mental health problems, (3) teacher's handling related to mental health problems, (4) mental health education, (5) parental involvement, and (6) efforts made by schools in improving mental health.

\section{Planning stage}

In this stage, instruments, leaflets, workbooks, and modules were developed which were later used in mental health programs development. In this preparation process, the research team used the Mood and Feelings Questionnaire (MFQ) instrument: Long Version. This instrument is a child self-report, which measures the emotional level and feelings experienced. Furthermore, the validated MFQ instrument was used in the acting stage of the identification process.

Workbooks were used to assess the appropriate interventions for the children. At the intervention stage, a handling module to be used as a guide was required. The module used was the development of therapy, which had been used in previous studies such as therapeutic, behavioral cognitive therapy, and violent behavior modules.

School-based Mental Health Program was conducted in accordance with the program flow shown in Figure 1.

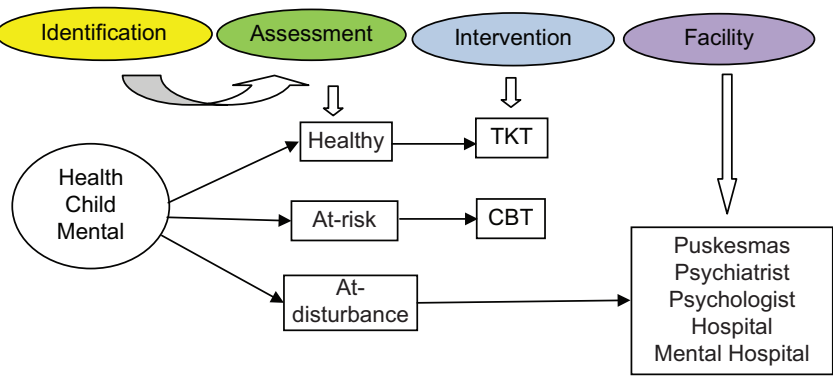

Figure 1: Program Flow of School-Based Mental Health Program

\section{Acting stage}

The first activity was to conduct teacher training related to the program that started from training to identify the mental health status of children, to conduct appropriate intervention evaluation, to make appropriate intervention, as well as facilitate/refer the child with problem.

At the identification and assessment stage, the research team and teachers jointly conducted the identification process through the distributed instruments. Subsequently, they were categorized into healthy, risk, and mental health problems statuses. At a later stage, at-risk children were considered to provide appropriate interventions to the experienced risk issues. Furthermore, the research team and teachers jointly performed therapeutic group therapy for healthy children, behavioral cognitive therapy for those at risk. Finally, when children with disorders were found, they will be facilitated to health services.

The mental health status that appeared were categorized as healthy, at-risk and at-disturbance, which can be seen in Table 1.

Table 1: Mental health status of school-age children at SD Negeri 060891 Medan $(n=73)$

\begin{tabular}{lll}
\hline Health Status & Frequency (f) & Percentage (\%) \\
Child Mentality & & \\
\hline Healthy & 52 & 71 \\
At-risk & 21 & 29 \\
At-disturbance & 0 & 0 \\
\hline
\end{tabular}




\section{Observation stage}

In this stage, the research team made an observation of the conducted program.

\section{Reflecting stage}

Activities undertaken at this stage measured the mental health status of school-aged children by comparing before and after the programs. Furthermore, data were processed using the dependent t-test. The difference in mean score before and after the program was 3.12 , and the results obtained $p=0.00$, which can be seen in Table 2 .

Table2: Mentalhealthstatusofschool-agechildren beforeandafter school-based mental health Program at SD Negeri 060891 Medan ( $n=73)$

\begin{tabular}{lllll}
\hline Child mental condition status & Mean & D & SE & p value \\
\hline Before & 83.14 & 10.843 & 1.269 & 0.00 \\
After & 86.26 & 11.548 & 1.358 & \\
Mean difference & 3.12 & & & \\
\hline
\end{tabular}

\section{Discussion}

The results showed that most children have a healthy mental condition, few have emotional issues, and no mental health problems. This is in accordance with Widyastuti [6] that most respondents $(74 \%)$ had no mental health problems, but no further examination was required, and a small or $26 \%$ probable problem needed further investigation. Recommendation from Widyastuti [6] was that parents and teachers need to pay more attention to growth and development, especially mental health.

In contrast to the above results, a study conducted on 161 respondents in Children and Youth Clinics of Cipto Mangunkusumo Hospital showed that $90 \%$ were less than 12 years old in primary school education, about $54.81 \%$ had relationship problems with their peers, and $42.2 \%$ had emotional issues [7]. In fact, these emotional problems were second with a substantial proportion (42.2\%), which include depression and anxiety. Wiguna et al. [7] reported that $33.6 \%$ of children came to mental health care centers with emotional problems, and girls under 12 years old tend to have these issues. Emotional problems were assessed to include depression and anxiety symptoms because at this age, children experience developmental crisis. Furthermore, they experience hormonal changes as well as alteration in environmental attitudes that further trigger the occurrence of emotional problems for children with certain vulnerabilities.

To anticipate the occurrence of health problems in school children, the government, in this case, the Ministry of Health as well as the Ministry of Education and Culture facilitated the existence of School Health
Enterprises (UKS) unit in each educational institution. The UKS is part of the efforts to maintain basic health, which is the burden of puskesmas to address tasks to schools with children and the environment to achieve the best state of child health and to maximally improve learning achievement [8].

The empowerment of school health effort was carried out by the implementing team in the school, especially conducted by the principal, teachers, or other health centers community that jointly established work areas. Furthermore, the empowerment of school health efforts in the learning process could be carried out in line with the physical or sports education activities in the subject matter that had been determined based on the curriculum. In this case, it was primarily concerned with the theoretical teaching of counseling, prevention, and treatment. The main UKS program or the triangle of UKS is health education, health service, and fostering healthy school environment. Based on these, the research team empowered the school teacher to improve UKS performance. Furthermore, teacher empowerment was focused on efforts to improve the health status of school children through psychosocial therapies implementation in children.

To support the government, school-based mental health programs are very suitable to be applied. The program flow started with the problems identification, in which the stages and assessment will facilitate teachers and health workers to know the health status of the children to administer appropriate interventions.

Mental health status can be categorized into 3, namely healthy, at-risk, and at-disorder. Healthy children will still be given intervention to prevent risk. Meanwhile, one of the psychosocial therapies that can be applied and had proven beneficial for growth and development is Therapeutic Therapy Group (TKT). This TKT aims to prevent the occurrence of mental health problems, which tend to occur in school-aged children such as violent behavior, emotional problems, and others.

TKT is a type of group therapy that gives members the opportunity to share experiences, help each other, find means to solve problems, and anticipate potential issues by teaching effective ways to control stress. Based on this understanding, therapeutic group therapy is performed to anticipate that no mental health problems occurred in children.

The TKT given to school-age children could improve motor, cognitive, language, emotional, personality, moral, spiritual, and psychosocial development. The results of TKT activities showed an increase in all developmental aspects with an average increase of 8 industrial development aspects with $17.26 \%$. Meanwhile, the development of most abilities in the cognitive aspect was $24.64 \%$, which was because the children always feel challenged in every stimulation in the given TKT challenge. 
At the time of this implementation, every child was required to channel all the possessed capabilities. Furthermore, the stimulation provided in TKT helped children to develop abilities that could not be developed within the school or home environment. In fact, group therapy could improve their ability to interact and behave in an adaptive manner. Children involvement in group activities in the neighborhood and school could assist them in developing their emotional, personal, and social aspects. In fact, the use of group therapy increased the ability to recognize their potential and to train these skills along with other group members because it could influence their behavior [9].

Istiana [10] showed that there was an increase in cognitive, psychomotor, and industrial development in the intervention groups of children-parents and childrenteachers compared to the control group. Furthermore, TKT was given in several sessions, each with a goal to be achieved. Children were given knowledge, played to improve motor skills, and also communicate with peers. It can be stated that knowledge is gained from one's own experience, or those given by others. Meanwhile, motor skills exercise could improve the ability to master certain skills. This is what reinforced the view that TKT is very important to be applied [11].

Those at risk of mental health problems could be intervened with Cognitive Behavior Therapy (CBT). This is a counseling approach that focuses on restructuring cognitive deviation due to events that physically or psychologically harm a student. Furthermore, this is directed to modifying the function of thinking, feeling, and acting, by emphasizing the brain as an analyzer, decision-maker, and resolver. Meanwhile, the approach to the behavioral aspect is directed to build a good relationship between the problem situation and the habit of reacting the problem. In addition, CBT makes individuals learn to change their behaviors, calm the mind and body to feel better, think more clearly, and to help them make the right decisions.

\section{Conclusion}

The mental health status score of schoolaged children before and after the program was 83.14 and 86.26, respectively (score difference of 3.12). Meanwhile, changes in the score showed significant alterations, meaning that there was a change in mental health status. These data were supported by the dependent T-Test results, which obtained $p=0.000$; alpha 0.05 . This showed that there was a significant influence of the programs implementation on the mental health status of children. Furthermore, the programs included identification, assessment, intervention, and mental health facilitation in school-aged children.
Therefore, this study recommended that schools need to apply school-based mental health programs and train classroom teachers to conduct it independently.

\section{Acknowledgments}

The author would like to thank the Ministry of Research and Technology Higher Education of Indonesia, Prof. Dr. Runtung, SH, M. Hum as the Rector of University of North Sumatera.

\section{References}

1. Santrock JW. Child Development. $11^{\text {th }}$ ed. Dallas: The McGrawHill Companies; 2007.

2. Stuart GW. Principles and Practice of Psychiatric Nursing. $10^{\text {th }}$ ed. South Carolina: Elsevier; 2013.

3. Ballard KL, Sander MA, Klimes-Dougan B. Schoolrelated and social-emotional outcomes of providing mental health services in schools. Community Ment Health J. 2014;50(2):145-9. https://doi.org/10.1007/s10597-013-9670-y PMid:24337471

4. Rones M, Hoagwood K. School-based mental health services: A research review. Clin Child Fam Psychol Rev. 2000;3(4):223-41. PMid: 11225738

5. Kemmis S, McTaggart R, Nixon R. The Action Research Planner, Doing Critical Participatory Action Research. London: Springer; 2014. p. 85-114. https://doi.org/10.1007/978-981-4560-67-2_5

6. Widyastuti O. Deteksi Dini Kesehatan Jiwa Anak Yang Mengalami Penurunan Prestasi Belajar; 2013. Available from: http://www.download.portalgaruda.org/article. php?article $=362323 \& \mathrm{val}=278 \&$ title $=$ deteksi. [Last accessed on 2017 Sep 12].

7. Wiguna TP, Pamela C. Pamela C. Masalah Emosi dan Perilaku Pada Anak dan Remaja Dipoliklinik Jiwa Anak dan Remaja RSUPN dr. Jakarta: Ciptomangunkusumo (RSCM); 2010. Available from: https://www.google.co.id/ url? sa $=\mathrm{t} \& \mathrm{rct}=\mathrm{j} \& \mathrm{q}=\&$ esrc $=\mathrm{s} \&$ source $=\mathrm{web} \& \mathrm{~cd}=17 \& \mathrm{cad}=$ \&ua . [Last accessed on 2017 Sep 12]. https://doi.org/10.14238/ sp12.4.2010.270-7

8. Susanti A. Penerapan Terapi Kelompok Terapeutik Dalam Peningkatan Pencapaian Tugas Perkembangan Industri Pada Anak Usia Sekolah; 2015. Available from: http://www. ejournal.stikesppni.ac.id/index.php/keperawatan-bina-sehat/ article/view/334. [Last accessed on 2017 Sep 12]. https://doi. org/10.26714/jkj.7.2.2019.229-234

9. Webb NB. Play therapy for bereaved children:Adapting strategies to community, school and home setting. Sch Psychol Int. 2011;32(2):132-43. https://doi.org/10.1177/0143034311400832

10. Istiana D. Terapi Kelompok Terapeutik Anak Usia Sekolah Pada Anak Orang Tua dan Anak Guru Meningkatkan Perkembangan Mental Anak Usia Sekolah; 2011. https://doi.org/10.36696/ mikia.v3i1.61

11. Tohirin T. Bimbingan dan Konseling di Seklah dan Madrasah (Berbasis Integral). Jakarta: PT. Raja Grafindo Persada; 2008. ISBN.9780470486887 